Pengaruh Motivasi Kerja dan Kepuasan Kerja Terhadap Komitmen Organisasi Pegawai Perusahaan Pada Mitra PT. PLN (Persero) Ulp Kota Bima

\title{
PENGARUH MOTIVASI KERJA DAN KEPUASAN KERJA TERHADAP KOMITMEN ORGANISASI PEGAWAI PERUSAHAAN PADA MITRA PT. PLN (PERSERO) ULP KOTA BIMA
}

\author{
Nurseha \\ Sekolah Tinggi Ilmu Ekonomi \\ Bima nseha768@gmail.com \\ Muhammad Yusuf \\ Sekolah Tinggi Ilmu Ekonomi Bima \\ yusufzm.stiebima@gmail.com
}

\begin{abstract}
This study aims to determine the effect of work motivation and job satisfaction on organizational commitment of company employees at partners PT.PLN (Persero) ULP Kota Bima. This research was conducted at Partners PT.PLN (Persero) ULP Kota Bima. This research was conducted using associative research. The population used in this research is 46 employees of the contract at partners of PT. PLN (Persero) Ulp. Bima City are 46 employees. With a research sample of 34 permanent employees, with the sampling technique using purposive sampling technique. Data collection techniques used, 1, observation, 2 documentation, 3, questionnaire 4, literature study. The data analysis technique used is, validity test, reliability test, classic assumption test, normality test, multicolinearity test, heteroscedasticity test, correlation coefficient test, determination coefficient test, multiple regression analysis test, hypothesis test ( $t$ test and $F$ test). The results of this study indicate that Work Motivation and Job Satisfaction simultaneously influence the Company's Employee Organizational Commitment at Partners PT PLN (Persero) ULP Kota Bima.
\end{abstract}

Keywords: Work Motivation, Job Satisfaction, Organizational Commitment.

\begin{abstract}
ABSTRAK
Penelitian ini bertujuan untuk mengetahui Pengaruh Motivasi kerja dan Kepuasan Kerja terhadap Komitmen Organisasi Pegawai Perusahaan Pada Mitra PT.PLN(Persero) ULP. Kota Bima. Penelitian ini dilakukan Pada Mitra PT.PLN(Persero) ULP. Kota Bima. Penelitian ini dilakukan dengan menggunakan jenis penelitian asosiatif. Populasi yang di gunakan dalam penelitian ini Pegawai kontrak pada mitra PT.PLN (persero) ULP. Kota Bima sejumlah 46 pegawai. Dengan sampel penelitian 34 karyawan Tetap, dengan tekhnik pengambilan sampel menggunakan teknik purposive sampling. Teknik pengumpulan data yang di gunakan , 1,observasi, 2 dokumentasi, 3, kuisoner 4, studi pustaka. Teknik analisa data yang di gunakan, Uji Validitas, Uji Realibilitas, Uji Asumsi Klasik, Uji Normalitas, Uji Multikolineritas, Uji Heteroskedastisitas, Uji koefesien korelasi, Uji koefesien Determinasi, Uji Analisis regresi Berganda, Uji hipotesi (Uji t dan Uji F). Hasil penelitian ini menunjukan bahwa Motivasi Kerja dan Kepuasan kerja bersamaan berpengaruh secara simultan terhadap Komitmen Organisasi Pegawai Perusahaan Pada Mitra PT. PLN(Persero) ULP Kota Bima.

Kata kunci : Motivasi Kerja, Kepuasan Kerja, Komitmen Organisasi.
\end{abstract}




\section{PENDAHULUAN}

Dewasa ini pegawai dipandang sebagai salah satu aset perusahaan yang penting dan perludikelola serta dikembangkan untuk mendukung kelangsungan hidup perusahaan. Dalam persaingan global, perusahaan dihadapkan dalam tantangan besar untuk menenangkan persaingan, sehingga dibutuhkan taktik dan strategi yang akurat. Menurut (Hasibuan, 2012) sumber daya manusia yang handal mampu menolong organisasi mampu menghadapi tantangan persaingan global. Pegawai adalah pelaksana utama setiap fungsi organisasi terhadap sarana, prasarana dan instruktur yang ada. Pegawai merupakan salah satu faktor kunci organisasi yang harus diperhatikan karena selalu mengalami berbagai dinamika di dalam organisasi. Salah satu hal penting yang harus diperhatikan adalah motivasi. Motivasi merupakan suatu proses yang mengakibatkan, mengarahkans dan menjaga atau memelihara perilaku manusia agar terarah pada tujuan. Untuk lebih meningkatkan performance dan sikap positif, sebaiknya menggunakan dan berpusat pada faktor motivasi. Listrik merupakan pendorong kegiatan ekonomi dan peningkatan kualitas kehidupan manusia. Tidak dapat dipungkiri bahwa listrik adalah salah satu energi yang paling dibutuhkan manusia untuk bertahan
hidup.PT PLN (Persero) sebagai perusahaan yang menyediakan listrikdi Indonesia terus berusaha menyediakan pelayanan terbaik bagi pelanggannya, sehingga menuntut semua elemen yang terlibat di dalamnya untuk terus meningkatkan kinerja atau performa kerjanya. Peran pemimpin dalam sebuah organisasi bukanlah hal yang mudah, namun sebagai seorang pemimpin untuk berbuat adil merupakan pekerjaan yang sulit, mengingat setiap pegawai memilikikarakteristik yang berbeda - beda. Perilaku adil bagi seorang pegawaibelum tentu dinilai adil oleh pegawai lainnya. Hubungan yang dekat serta komunikasi yang baik antara seorangpemimpin dan pegawainya merupakan salah satu cara yang dapat memberikan motivasi kerja kepada pegawai sehingga pegawai merasa dihargai. Manusia pada dasarnya mudah untuk dimotivasi dengan memberikan apa yang menjadi keinginannya. Seorang pegawai yang termotivasi, pegawai tersebut akan sekuat tenaga bekerja keras melakukan pekerjaannya dengan baik untuk keberhasilan organisasi. Kerja keras yang dilakukan dengan adanya dorongan atau motivasi akan menghasilkan sebuah kepuasan tersendiri bagi pegawai dalam melakukan pekerjaannya. Kepuasan kerja dan motivasi kerja yang dirasakan oleh 
Pengaruh Motivasi Kerja dan Kepuasan Kerja Terhadap Komitmen Organisasi Pegawai Perusahaan Pada Mitra PT. PLN (Persero) Ulp Kota Bima

pegawai dapat menurunkan komitmen organisasi ataupun meningkatkan komitmen organisasi pegawai. Pegawai yang merasa puas dengan pekerjaan yang diperoleh akan termotivasi untuk meningkatkan kinerja sehingga akan berdampak pada meningkatnya keberhasilan organisasi. Pegawai yang bekerja dengan senang hati dan tanpa adanya paksaan akan memberikan hasil yang baik dan akan menumbuhkan komitmen organisasional Pegawai terhadap organisasi. Berdasarkan hasil observasi pada perusahaan Mitra PT. PLN (Persero) Ulp. Kota Bima temukan beberapa masalah dimana masih

\section{TELAAH LITERATUR}

\section{Kepuasan Kerja (X)}

(Hani, 2015) Kepuasan kerja adalah keadaan emosional yang menyenangkan atau tidak menyenangkan dengan mana para pegawai memandang pekerjaan mereka.kepuasan kerja merupakan sikap umum yang merupakan hasil dari beberapa sifat khusus terhadap faktor-faktor pekerjaan, penyesuaian diri dan hubungan sosial individu di luar kerja. (Hasibuan, Motivasi Kerja (X)

Motivasi kerja menurut (Feriyanto \& Shyta, 2015) adalah suatu sugesti atau dorongan yang muncul karena diberikan oleh seseorang kepada orang lain atau dari diri sendiri. Menurut McClelland dalam kurangnya pemberian motivasi daripimpinan dimana dalam bekerja pegawai masih kurang bersemangat dikarenakan kurangnya pemantauan dan koordinasi dari pemimpin. Terkait kepuasan kerja dirasakan pegawai karena sistem penggajian yang kurang bagus sehingga terdapat menurunnya sikap komitmen pegawai dalam bekerja. Berdasarkan pemaparan permasalahan tersebut maka peneliti tertarik melakukan penelitian dengan judul "Pengaruh Motivasi Kerja Dan Kepuasan Kerja Terhadap Komitmen Organisasi Pegawai Perusahaan Pada Mitra PT. PLN (persero) ULP Kota Bima”.

2012) bahwa indikator kepuasan kerja pegawai dapat dilihat dari beberapa hal sebagai berikut :

1. Kepuasan terhadap pekerjaan

2. Kepuasan terhadap peraturan dan sikap atasan

3. Kepuasan terhadap rekan kerja

4. Kepuasan terhadap promosi

5. Kepuasan terhadap Gaji/Kompensasi

(Robbins \& Judges, 2011) indikatorindikator motivasi kerja adalah:

1. Kebutuhan akan kekuasaan

2. Kebutuhan untuk berprestasi

3. Kebutuhan akan afiliasi 


\section{Komitmen Organisasional (Y)}

Komitmen organisasional didefinisikan sebagai kekuatan yang bersifat relatif dari individu dalam mengidentifikasikan keterlibatan dirinya kedalam bagian organisasi, yang dicirikan oleh penerimaan nilai dan tujuan organisasi, kesediaan berusaha demi organisasi dan keinginan mempertahankan keanggotaan dalam

Pengaruh Kepuasan Kerja dan Motivasi

\section{Kerja Terhadap Komitmen}

Organisasional.

Secara teoritis disebutkan bahwa kepuasan kerja adalah sebagai konsep praktis yang sangat penting, karena merupakan dampak dari keefektifan performance dan kesuksesan dalam bekerja, sementara kepuasan yang rendah pada organisasi adalah sebagai rangkaian penurunan moral organisasi dan meningkatnya absensi. Kepuasan kerja pegawai dan kondisi kerja yang baik mempunyai hubunga kerja yang signifikan dengan kinerja, selanjutnya pegawai yang merasa puas dengan pekerjaannya biasanya mereka bekerja lebih keras dan lebih baik dibanding dengan pegawai yang mengalami stress yang disebabkan dengan kondisi kerja yang tidak kondusif. Kepuasan kerja dan

\section{METODOLOGI PENELITIAN}

Jenis penelitian ini termaksud penelitian asosiatif. Penelitian asosiatif merupakan suatu penelitian yang bertujuan untuk mengetahui pengaruh atau hubungan antara organisasi. (Robbins \& Judges, 2011). Menurut Allen dan Mayer dalam (Robbins S. , 2012) mengemukakan bahwa terdapat tiga dimensi terpisah komitmen organisasional, yaitu :

1. Affective commitment

2. Continuance commitment

3. Normative

sikap pegawai merupakan suatu hal yang penting dalam menentukan perilaku dan respon terhadap pekerjaan dan melalui perilaku tersebut organisasi yang efektif dapat tercapai. Untuk melihat pengaruh Kepuasan Kerja Dan Motivasi Kerja Terhadap Komitmen Organisasi dapat dilihat dari penelitian terdahulu yang bisa kita jadikan acuan diantaranya penelitian yang dilakukan oleh (Ari \& Sriathi, 2018), menyatakan bahwa Kepuasan Kerja Dan Motivasi Kerja berpengaruh positif dan signifikan terhadap Komitmen Organisasional Pada The Kirana Hotel Resto and Spa Canggu Bali dan (Tania \& Sutanto, 2013).

dua variabel atau lebih (sugiyono, 2012:26). Instrumen penelitian yang digunakan yaitu kuesioner yang berisi sejumlah pertanyaan dengan pengukuran 
skala Likert. Adapun populasi yang digunakan yaitu 46 orang pegawai yang berkerja di perusahaan pada mitra PT. PLN (persero) Ulp. Kota Bima. Teknik sampling yang di gunakan adalah sampling purposive sesuai dengan kebutuhan peneliti yaitu jumlah samplenya 34 orang pegawai kontrak sebagai responden. Menyatakan bahwa Kepuasan Kerja Dan Motivasi Kerja berpengaruh positif dan signifikan terhadap Komitmen Organisasional Pada Karyawan PT. Dai Knife. Dalam penelitian ini untuk mengukur variabel bebas dan terkait maka

\section{HASIL DAN PEMBAHASAN}

\section{Uji Validitas}

Dalam penelitian ini uji validitas dilakukan dengan membandingkan $r$ tabel dengan $r$ hitung yang dimana $\mathrm{N}=34$ dengan taraf digunakan kusioner yang bersifat tertutup dimana responden diberi altenatif pilihan jawaban pada setiap pertanyaan .kusioner dibagikan pada sejumlah responden dan seluruh item variabel akan diukur menggunakan skala likert sebagai berikut:

- Jawaban sangat setuju akan diberi skor 5

- Jawaban setuju diberi skor 4

- Jawaban netral diberi skor 3

- Jawaban tidak setuju diberi bobot 2

- Jawaban sangat tidak setuju diberi skor 1

signifikan $5 \%$ maka diperoleh $\mathrm{r}$ sebesar 0,339 , untuk lebih jelasnya dapat dilihat seperti tabel dibawah ini:

\begin{tabular}{|c|c|c|c|c|}
\hline \multirow{4}{*}{ Variabel } & indikator & $\begin{array}{c}\text { Total } \\
\text { Pearson } \\
\text { Corelation }\end{array}$ & $\begin{array}{c}\mathrm{R} \\
\text { Tabel }\end{array}$ & Keterangan \\
\hline \multirow{4}{*}{$\begin{array}{l}\text { Motivasi } \\
\text { Kerja (X1) }\end{array}$} & $\mathrm{X} 1.1$ & 0,300 & 0,339 & Valid \\
\cline { 2 - 5 } & $\mathrm{X} 1.2$ & 0,300 & 0,339 & Valid \\
\cline { 2 - 5 } & $\mathrm{X} 1.3$ & 0,300 & 0,339 & Valid \\
\cline { 2 - 5 } & $\mathrm{X} 1.4$ & 0,300 & 0,339 & Valid \\
\cline { 2 - 5 } & $\mathrm{X} 1.6$ & 0,300 & 0,339 & Valid \\
\hline \multirow{5}{*}{$\begin{array}{l}\text { Kepuasan } \\
\text { Kerja (X2) }\end{array}$} & $\mathrm{X} 2.1$ & 0,300 & 0,339 & Valid \\
\cline { 2 - 5 } & $\mathrm{X} 2.2$ & 0,300 & 0,339 & Valid \\
\cline { 2 - 5 } & $\mathrm{X} 2.3$ & 0,300 & 0,339 & Valid \\
\cline { 2 - 5 } & $\mathrm{X} 2.5$ & 0,300 & 0,339 & Valid \\
\hline \multirow{4}{*}{ Komitmen } & $\mathrm{X} 2.6$ & 0,300 & 0,339 & Valid \\
\cline { 2 - 5 } & $\mathrm{Y} 1.1$ & 0,300 & 0,339 & Valid \\
\cline { 2 - 5 } & $\mathrm{Y} 1.3$ & 0,300 & 0,339 & Valid \\
\hline
\end{tabular}




\section{Uji Reliabilitas}

\begin{tabular}{|l|c|c|c|c|}
\cline { 2 - 5 } $\begin{array}{l}\text { Organisasi } \\
\text { onal }\end{array}$ & Y1.4 & 0,300 & 0,342 & Valid \\
\cline { 2 - 5 } $\begin{array}{l}\text { Pegawai } \\
\text { (Y) }\end{array}$ & Y1.5 & 0,300 & 0,343 & Valid \\
\cline { 2 - 5 } & Y1.6 & 0,300 & 0,344 & Valid \\
\hline
\end{tabular}

Uji reliabilitas pada penelitian ini yaitu reliabel harus $>0,60$, selengkapnya dapat membandingkan standar reliabel dengan dilihat seperti pada tabel dibawah ini : cronbach's alpha yang dimana standar

\section{Uji Asumsi Klasik}

\begin{tabular}{|l|c|c|}
\hline \multicolumn{1}{|c|}{ Variabel } & $\begin{array}{c}\text { Cronbach's } \\
\text { Alpha }\end{array}$ & $\begin{array}{c}\text { Keteran } \\
\text { gan }\end{array}$ \\
\hline Motivasi Kerja & 0,689 & Reliabel \\
\hline Kepuasan Kerja & 0,752 & Reliabel \\
\hline $\begin{array}{l}\text { Komitmen } \\
\text { Organisasi } \\
\text { onal } \\
\text { Pegawai }\end{array}$ & 0,773 & Reliabel \\
\hline
\end{tabular}

\section{Uji Normalitas}

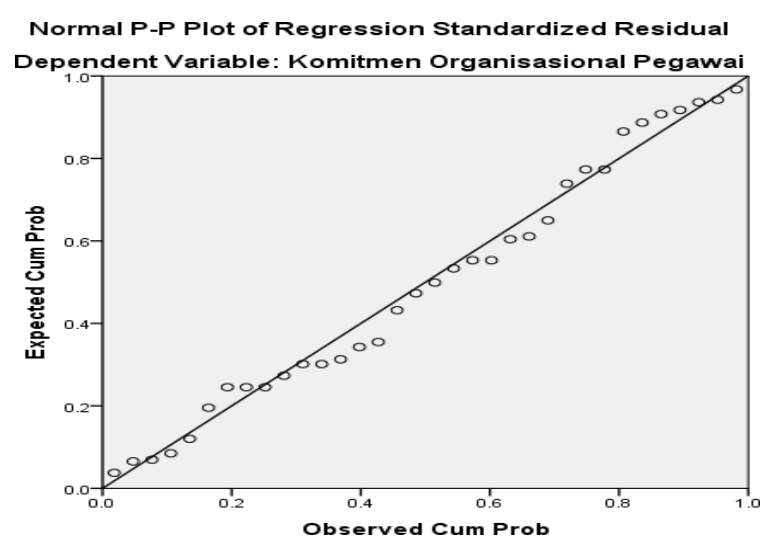

Grafik P-P Plot Regression Standardized disimpulkan bahwa data penelitian Residual diatas menunjukan butiran bola berdistribusi normal. mengikuti garis diagonal maka dapat

\section{Uji Multikolinearitas}

\begin{tabular}{|l|l|r|r|}
\hline \multicolumn{2}{|l|}{ Model } & \multicolumn{2}{|c|}{ Collinearity Statistics } \\
\cline { 3 - 4 } \multicolumn{2}{|l}{} & \multicolumn{1}{|c|}{ Tolerance } & \multicolumn{1}{c|}{ VIF } \\
\hline \multirow{2}{*}{1} & (Constant) & & 1.924 \\
\cline { 2 - 4 } & Motivasi Kerja & 0.52 & 1.924 \\
\cline { 2 - 4 } & Kepuasan Kerja & 0.52 & \\
\hline
\end{tabular}


Pengaruh Motivasi Kerja dan Kepuasan Kerja Terhadap Komitmen Organisasi Pegawai Perusahaan Pada Mitra PT. PLN (Persero) Ulp Kota Bima

Berdasarkan tabel diatas bahwa variabel maka data tersebut tidak terjadi $\mathrm{X} 1$ dan X2 nilai VIF nya adalah $1,924<$ Multikolinieritas.

10,00 dan nilai tolerance value $0,52>0,1$

\section{Uji Heterokedestisitas}

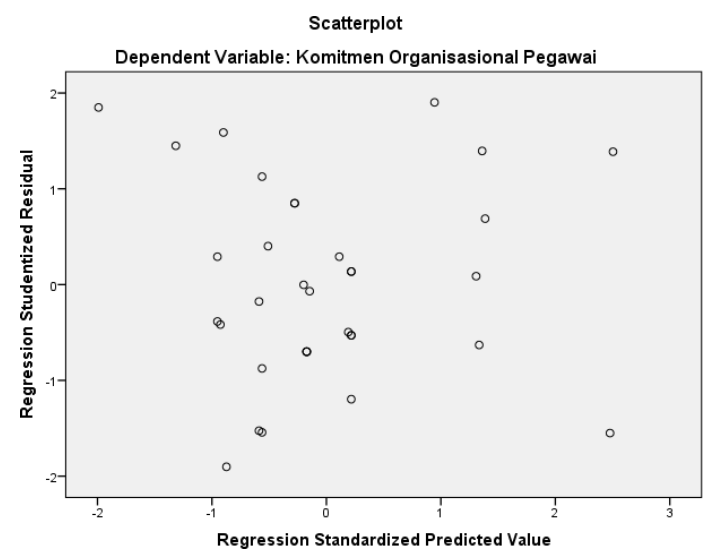

Berdasarkan grafik Scatterplot diatas disimpulkan bahwa data tersebut tidak bahwa butiran bola menyebar luas dan terjadi residual.

tidak membentuk suatu pola maka dapat

\section{Uji Autokorelasi}

\begin{tabular}{|l|c|c|r|r|c|}
\hline \multicolumn{5}{|c|}{$\begin{array}{l}\text { Model } \\
\text { Summary }\end{array}$} \\
\hline Model & $\mathrm{R}$ & $\begin{array}{c}\mathrm{R} \\
\text { Squar } \\
\mathrm{e}\end{array}$ & $\begin{array}{c}\text { Adjusted R } \\
\text { Square }\end{array}$ & $\begin{array}{c}\text { Std. } \\
\text { Error } \\
\text { of the } \\
\text { Estimate }\end{array}$ & $\begin{array}{c}\text { Durbin- } \\
\text { Watson }\end{array}$ \\
\hline 1 & $\begin{array}{c}.789 \\
\mathrm{a}\end{array}$ & .623 & 0.598 & 1.529 & 1.377 \\
\hline \multicolumn{5}{|l|}{} \\
\hline \multicolumn{5}{|l|}{ b. Predictors: (Constant), Kepuasan Kerja, Motivasi Kerja } \\
\hline
\end{tabular}

Berdasarkan tabel diatas untuk nilai durbinwatson nya yaitu sebesar 1,377 lebih kecil dari batas atas (du) yakni 1,652 dan kurang dari (4-du) 4-1,652 = 2,348 maka dapat disimpulkan bahwa tidak terdapat masalah atau gejala autokorelasi 


\section{Analisis Regeresi Linear Berganda}

\begin{tabular}{|c|c|c|c|c|c|c|}
\hline & & & Coeffici & $n t^{a}$ & & \\
\hline & & $\begin{array}{l}\text { Unstan } \\
\text { Coeff }\end{array}$ & $\begin{array}{l}\text { ardized } \\
\text { cients }\end{array}$ & $\begin{array}{l}\text { Standardized } \\
\text { Coefficients }\end{array}$ & $\mathrm{t}$ & Sig. \\
\hline & & B & $\begin{array}{l}\text { Std. } \\
\text { Error }\end{array}$ & Beta & & \\
\hline & (Constant) & 5.984 & 2.968 & & 2.016 & .053 \\
\hline 1 & $\begin{array}{l}\text { Motivasi } \\
\text { Kerja }\end{array}$ & .050 & .176 & .043 & .284 & .778 \\
\hline & $\begin{array}{l}\text { Kepuasan } \\
\text { Kerja }\end{array}$ & .692 & .140 & .758 & 4.956 & .000 \\
\hline & eendent $\mathrm{V}$ & ble: Ko & itmen ( & rganisasional & gawai & \\
\hline
\end{tabular}

Berdasarkan tabel di atas variabel terikat pada penelitian ini yaitu komitmen organisasional pegawai sedangkan untuk variabel bebasnya yaitu motivasi kerja dan kepuasan kerja maka persamaan regresinya sebagai berikut $: \mathrm{Y}=\mathrm{a}+\mathrm{b} 1 \mathrm{X} 1+\mathrm{b} 2 \mathrm{x} 2$

$\mathrm{Y}=5,984+0,50 \mathrm{X} 1+0,692 \mathrm{X} 2$

Yang dimana

$\mathrm{Y}=$ variabel terikat

b1 = koefisien regresi X1 ,

$\mathrm{X} 1$ = variabel bebas $\mathrm{X} 1$,

$\mathrm{a}=$ konstanta

b2 = koefisien garis regresi X2,

$\mathrm{X} 2$ = variabel bebas $\mathrm{X} 2$.

a) Nilai constanta ialah 5,984 artinya jika tidak terjadi perubahan variabel kepuasan kerja dan motivasi kerja

\section{Koefisien Korelasi}

Dapat dilihat nilai koefisien korelasi (R) variabel motivasi kerja dan kepuasan kerja sebesar 0,789. Maka dapat diketahui bahwa terjadi hubungan yang kuat antara motivasi kerja dan kepuasan kerja terhadap adalah 0 maka komitmen organisasional pada Mitra PT. PLN (Persero) Ulp Kota Bima yaitu sebesar 5,984 .

b) Kepuasan kerja (X1) yaitu sebesar 0,050 yang berarti variabel kepuasan kerja dengan asumsi variabel motivasi kerja (X2) meningkat sebesar 0,050 terhadap komitmen organisasional pada Mitra PT. PLN (Persero) Ulp Kota Bima.

c) Motivasi kerja (X2) mempunyai nilai koefisien regresi yaitu sebesar 0,692 dengan asumsi variabel kepuasan kerja (X1) terhadap komitmen organisional Mitra Pt.Pln (Persero) Ulp Kota Bima komitmen organisasional pegawai sebesar $78,9 \%$. sedang untuk $21,1 \%$ sisa nya dipengaruhi oleh variabel yang lain yang tidak diteliti dalam penelitian ini. 


\section{Koefisien Determinasi}

Koefisien determinasi ( $\mathrm{R}$ Square) yang komitmen organisasional pegawai sebesar diperoleh pada penelitian ini sebesar 0,623 menunjukan bahwa variabel motivasi kerja dan kepuasan kerja hanya mempengaruhi 62,3\%. Dan untuk $37.7 \%$ sisanya dipengaruhi oleh variabel yang tidak di teliti dalam penelitian ini.

\section{Uji t}

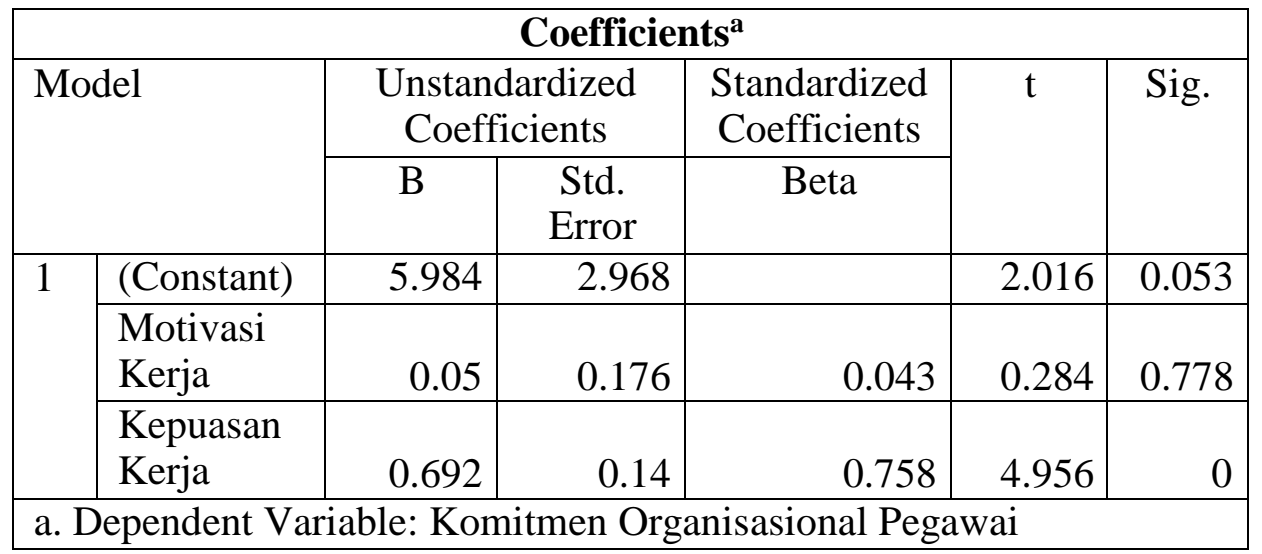

Berdasarkan tabel diatas diketahui :

1. $\mathrm{t}$ hitung variabel motivasi kerja sebesar 0,284 < t tabel yaitu 2,040 dan niai sig $0,778>0,05$ yang artinya bahwa Ha ditolak dan Ho diterima, jadi kesimpulan nya yaitu tidak terdapat pengaruh motivasi kerja terhadap komitmen organisasional pegawai Pada Mitra Pt.Pln (Persero) Ulp Kota Bima.
2. $\mathrm{t}$ hitung variabel kepuasan kerja sebesar 4,956 > t tabel yaitu 2,040 dan nilai sig $0<0,05$ yang artinya bahwa Ho ditolak dan Ha diterima, jadi kesimpulan nya yaitu terdapat pengaruh kepuasan kerja terhadap komitmen organisasional pegawai Pada Mitra PT. PLN (Persero) Ulp. Kota Bima.

Uji f

\begin{tabular}{|c|c|c|c|c|c|c|}
\hline \multicolumn{7}{|c|}{ ANOVA $^{a}$} \\
\hline \multicolumn{2}{|c|}{ Model } & Sum of & $\mathrm{df}$ & Mean & $\mathrm{F}$ & Sig. \\
\hline \multirow{3}{*}{1} & Regression & 119.583 & 2 & 59.792 & 25.585 & $.000^{\mathrm{b}}$ \\
\hline & Residual & 72.446 & 31 & 2.337 & & \\
\hline & Total & 192.029 & 33 & & & \\
\hline \multicolumn{7}{|c|}{ a. Dependent Variable: Komitmen Organisasional Pegawai } \\
\hline
\end{tabular}


Berdasarkan tabel diatas dapat dilihat $\mathrm{F}$ hitung sebesar 25,585 dengan nilai $\mathrm{F}$ tabel adalah 3,29 sehingga nilai $\mathrm{F}$ hitung $>\mathrm{F}$ tabel atau 25,585 > 3,29 dan tingkat signifikasi $0,000<0,05$ maka Ho di tolak dan Ha diterima, yang berarti variabel

\section{SIMPULAN}

Hasil uji $\mathrm{t}$ menunjukan $\mathrm{t}$ hitung variabel motivasi kerja sebesar 0,284 < t tabel yaitu 2,040 dan niai sig 0,778 > 0,05 yang artinya bahwa Ha ditolak dan Ho diterima, jadi kesimpulan nya yaitu tidak terdapat pengaruh motivasi kerja terhadap komitmen organisasional pegawai Pada Mitra PT. PLN (Persero) Ulp. Kota Bima. Dan $\mathrm{t}$ hitung variabel kepuasan kerja sebesar 4,956 > t tabel yaitu 2,040 dan nilai sig $0<0,05$ yang artinya bahwa Ho ditolak dan Ha diterima, jadi kesimpulan nya yaitu terdapat pengaruh kepuasan kerja terhadap

\section{DAFTAR PUSTAKA}

Ari, S., \& Sriathi. (2018). Pengaruh Motivasi Kerja dan Kepuasan Kerja Terhadap Komitmen

Organisasional. E-Jurnal

Manajemen Unud, Vol. 7, No. 9, 4628-4656.

Feriyanto, A., \& Shyta, T. (2015). Pengantar Manajemen (3 in 1),. Yogyakarta: Penerbit Media Tera.

Hani, H. T. (2015). Manajemen, Edisi 2. Yogyakarta: BPFE.

Hasibuan, M. (2012). Manajemen SDM. motivasi kerja dan kepuasan kerja secara simultan berpengaruh secara signifikan terhadap komitmen organisasional pegawai Pada Mitra PT. PLN (Persero) Ulp. Kota Bima.

komitmen organisasional pegawai Pada Mitra PT. PLN (Persero) Ulp. Kota Bima. Hasil uji f $F$ hitung sebesar 25,585 dengan nilai $F$ tabel adalah 3,29 sehingga nilai $F$ hitung > F tabel atau 25,585 > 3,29 dan tingkat signifikasi $0,000<0,05$ maka Ho di tolak dan Ha diterima, yang berarti variabel motivasi kerja dan kepuasan kerja secara simultan berpengaruh secara signifikan terhadap komitmen organisasional pegawai perusahaan Pada PT. PLN (Persero) Ulp. Kota Bima.

Edisi Revisi, Cetakan Ke Tigabelas. Jakarta: Bumi Aksara.

Robbins, S. (2012). Perilaku Oganisasi. . Jakarta: Salemba Empat.

Robbins, S., \& Judges. (2011). Perilaku Organisasi, . Jakarta: Salemba Empat.

Sugiyono. (2012). Metode Pendekatan Penelitian Kuantitatif-Kualitatif. Bandung: Alfabeta.

Sugiyono. (2017). Metode Penelitian Kuantitatif, Kualitatif dan $R \& D$ 
Pengaruh Motivasi Kerja dan Kepuasan Kerja Terhadap Komitmen Organisasi Pegawai Perusahaan Pada Mitra PT. PLN (Persero) Ulp Kota Bima

(edisi 26). Bandung: Alfabeta.

Organisasional Karyawan PT. DAI

Tania, \& Sutanto. (2013). Pengaruh KNIFE di Surabaya. Agora Vol. 1, Motivasi Kerja dan Kepuasan Kerja No.3.

Terhadap Komitmen 